\title{
MODEL HUBUNGAN KARAKTERISTIK SUMBER DAYA MANUSIA TERHADAP KINERJA PEGAWAI DI LINGKUNGAN INDUSTRI INFORMASI GEOSPASIAL
}

\author{
Immas Nurhayati ${ }^{1)}$, Budi Susetyo ${ }^{2)}$, Indu Purnahayu ${ }^{3)}$, dan Puspa Eosina ${ }^{4) .}$ \\ ${ }^{1}$ Manajemen, Fakultas Ekonomi dan Bisnis,Universitas Ibn Khaldun Bogor \\ ${ }^{2,4}$ Teknik Informatika, Fakultas Teknik dan Sain,Universitas Ibn Khaldun Bogor \\ ${ }^{3}$ Manajemen, Sekolah Pascasarjana,Universitas Ibn Khaldun Bogor \\ ${ }^{1,2,3,4} \mathrm{Jl}$. KH Sholeh Iskandar KM 2 Bogor, 16164
}

E-mail : immasnurhayati1@gmail.com ${ }^{1)}$, budiuika@yahoo.com²), indupurnahayu@yahoo.co.id ${ }^{3)}$, puspa.eosina@ $\mathrm{ft}^{2}$ uika-bogor.ac.id ${ }^{4)}$

\begin{abstract}
ABSTRAK
Perkembangan pesat dalam komputasi dan infrastruktur teknologi informasi telah menyebabkan peningkatan kemampuan untuk menangani sejumlah besar data geospasial. Penggunaan data spasial tidak hanya terbatas pada penggunaan geografi, tetapi pada bidang-bidang lain, terutama bidang yang terkait dengan penggunaan sumber daya alam dan kewilayahan. Untuk itu dibutuhkan sumber daya manusia yang tangguh dan berkualitas. Tujuan penelitian ini adalah untuk menganalisis hubungan karakteristik sumber daya manusia (SDM) dengan kinerja pegawai di lingkungan industri informasi geospasial menggunakan model logit pada data kualitatif dengan variabel dummy. Data yang diolah merupakan data yang diperoleh melalui penyebaran kuesioner pada 46 responden yang bekerja di beberapa perusahaan yang bergerak di bidang geospasial. Hasil uji wald menunjukkan, sumber daya manusia yang berusia lebih dari 50 tahun, berpendidikan SMU/SMA, belum mengikuti pelatihan geospasial, dengan masa kerja lebih dari 10 tahun, tidak signifikan memiliki kinerja yang lebih baik. Interpretasi dalam odd rasio dan exp (B) pada sebagian besar variabel yang diukur menunjukkan variabel usia, pendidikan, masa kerja tidak berbeda secara signifikan dalam mempengaruhi kinerja pegawai.
\end{abstract}

Kata Kunci: teknologi informasi, geospasial, variabel dummy, logit, kinerja pegawai.

\section{PENDAHULUAN}

Geospasial web services dan web mapping merupakan kebutuhan yang telah mendapatkan cukup perhatian dalam beberapa tahun terakhir. Sebagaimana disampaikan dalam laporan akhir tahun LAPAN memudahkan interoperabilitas informasi geospasial sumber daya alam (LAPAN, 2014). Informasi yang didapatkan saat ini berhubungan dengan spasial atau komponen geografi, artinya semua informasi terkait dengan lokasi atau tempat tidak terlepas dari posisi geografis atau data spasial. Teknologi geospasial adalah istilah yang digunakan untuk menggambarkan berbagai alat modern yang berkontribusi terhadap pemetaan dan analisis geografis.

Perkembangannya diawali dengan pengambilan informasi menggunakan cara dan wahana yang sangat sederhana hingga menerapkan teknologi foto udara melalui pemanfaatan data digital menggunakan satelit. Hal ini menunjukkan perubahan yang signifikan dalam pihak-pihak terkait. Teknologi ini menjadi salah satu teknologi yang banyak digunakan dalam berbagai keperluan pembangunan dalam upaya mempercepat penyampaian informasi wilayah atau daerah secara spasial. Informasi ini penting bagi perencanaan terkait dengan rencana pembangunan infrastruktur sumber daya alam maupun konstruksi di daerah. menunjukkan bahwa untuk semua kategori perangkat lunak yang digunakan dalam implementasi geospasial web services dan web mapping tersedia produk perangkat lunak bebas dan sumber terbuka serta mendukung berbagai standar industri yang perkembangan dan pemanfaatan teknologi ini dalam kehidupan sehari-hari

Penggunaan satelit, memungkinkan gambar permukaan bumi dan aktivitas manusia di dalamnya dengan keterbatasan tertentu, dapat diaqusisi secara detail tergantung pada tingkat resolusi yang digunakan. Dengan bantuan teknologi komputer dan pengolahan data spasial, dapat dilakukan analisis yang tepat mengenai bentuk dan karakteristik permukaan bumi. Aspek penting dari teknologi geospasial adalah kemampuannya untuk mengumpulkan berbagai data spasial ke dalam serangkaian peta berlapis yang memungkinkan tema kompleks dianalisis dan kemudian dishare

kepada

Salah satu contoh penerapan dan pemanfaatan teknologi geospasial dalam kehidupan sehari-hari adalah penggunaan sistem informasi geografis (SIG) untuk memproses data yang bergeoreferensi dan sekolah yang ada di kabupaten Rokan Hilir. SIG berbasis web memungkinkan untuk melihat peta lokasi dimana sekolah yang berhak menerima dana Bantuan 
operasional sekolah (BOS) dan telah mendapatkan dana bantuan operasional sekolah. Teknologi SIG ini mendukung keperluan penyebaran informasi dalam bentuk data atribut dan peta-peta untuk meningkatkan koordinasi dan keterpaduan penyebaran dana bantuan operasional sekolah (BOS). Hal yang terpenting adalah data penerimaan dana bantuan yang telah diterima oleh sekolah di kabupaten Rokan Hilir, sehingga pemberian bantuan dapat diterima secara merata oleh sekolah (Hamidi, 2012).

Contoh lain penerapan dan pemanfaatan teknologi informasi geospasial dalam kehidupan sehari hari adalah penggunaan aplikasi Web GIS menggunakan MySQL, XAMPP dan phpMyAdmin dalam memasarkan perumahan Bukit Sakinah. MySQL digunakan untuk merancang database system, XAMPP digunakan untuk web server dan phpMyAdmin digunakan untuk database server. Aplikasi ini juga menyediakan fitur seperti mengupdate data, mengedit data dan menghapus data warga perumahan bukit sakinah. Dengan adanya aplikasi ini diharapkan masyarakat dengan lebih mudah mencari informasi rumah di Perumahan bukit Sakinah dan memudahkan pihak kantor pemasaran Permahan Bukit Sakinah dalam menyediakan informasi perumahan bukit sakinah (Ramlan, Purwanto, Eosina, \& Susetyo, 2019).

Sistem informasi geospasial telah diterapkan dalam penyusunan data base rumah sakit dan pusat kesehatan masyakat di Kabupaten Lampung Timur. Hasil Penelitian menunjukkan melalui penerapan sistem informasi geospasial penyediaan data base rumah sakit dapat diketahui rumah sakit dengan kondisi baik dan memadai atau sebaliknya dengan persebaran yang cukup merata (Cahaya, 2018).

Sebagai bagian dari supporting system yang sangat menentukan keberhasilan pembangunan industri geospasial, keberadaan sumber daya manusia yang tangguh dan berkualitas sangat dibutuhkan. Pengembangan SDM informasi geospasial yang handal, baik dan berkualitas serta dalam jumlah yang memadai ditujukan untuk memenuhi kebutuhan pembangunan nasional dan menghadapi tantangan globalisasi. Penguatan sumber daya manusia dapat dimulai dari penguatan SDM di bidang Informasi Geospasial (IG). "Data statistik dan data spasial dibutuhkan untuk pembangunan negara, namun SDM di bidang Informasi Geospasial masih sedikit sehingga pemahaman dan pengaplikasian untuk pembangunan masih sulit untuk diterapkan menyeluruh. Oleh karena itu penguatan SDM IG berbasis kompetensi memiliki peran besar sebagaimana diamanatkan dalam Undang-undang Nomor 4 Tahun 2011 tentang IG (Abidin, 2017).

Rintisan pengembangan sumber daya manusia seiring perkembangan industri geospasial telah dilakukan sejak Indonesia tergabung dalam organisasi AEC sejak tahun 2015. Indonesia berupaya memiliki sumber daya manusia yang terampil dan kompeten dalam informasi geospasial. Secara populasi, saat ini Indonesia dengan jumlah penduduk sekitar 240 juta jiwa merupakan sepertiga dari total populasi Komunitas Ekonomi ASEAN memiliki potensi sangat besar untuk berkontribusi dalam industri geospasial. Telah dilakukan pemetaan pekerja terampil Indonesia dan proyeksi sumber daya manusia geospasial di Indonesia sampai tahun 2025, perlu adanya penguatan dalam aspek sumber daya manusia untuk menghadapi tantang global yang akan semakin berat (Nurhayati, Susetyo, Eosina, \& Purnahayu, 2017).

Untuk menghadapi tantangan tersebut, Badan Informasi Geospasial (BIG) membentuk Kelompok Kerja Penilaian Kesesuaian (KKPK) untuk membantu pelaksanaan sistem penilaian kesesuaian pada bidang IG. Salah satu infrastruktur yang sangat menentukan keberhasilan penyelenggaraan IG adalah sumber daya manusia. Pengembangan SDM IG dilaksanakan dengan pendekatan kebijakan antara lain penyelenggaraan sistem akreditasi dan sertifikasi kompetensi SDM IG.Untuk itu, diperlukan penyusunan Standar Kompetensi Kerja Nasional Indonesia (SKKNI) IG dan Kerangka Kualifikasi Nasional Indonesia (KKNI) bidang IG. Kebijakan lainnya berupa penyelenggaraan dan penguatan pendidikan dan pelatihan berbasis kompetensi, serta pengembangan kelembagaan IG yang kuat (Bardono, 2017).

Hasil survei BIG menunjukkan 64\% SDM IG masih bekerja di pulau Jawa, 9\% di Kalimantan, dan 5\% di Pulau Maluku. Sisanya, bekerja di Sulawesi, Papua, dan Nusa Tenggara. Bidang SDM IG tersebar meliputi bidang survey pemetaan, riset penelitian, perencanaan, pertanahan dan tata ruang, pertambangan, perkebunan, kehutanan, migas dan NGO. Hasil survei juga menunjukkan rendahnya penguasaan unit keahlian IG pada tingkatan operator dan analis. Hampir 60\% responden memiliki latar belakang pendidikan S1 dengan level keahlian tingkat analis namun penguasaan unit level keahlian masih terbatas pada level operator (Bardono, 2017).

Lebih jauh lagi, perkembangan aplikasi sistem informasi geospasial (SIG) tidak hanya pada jumlah namun juga pada keanekaragaman jenis aplikasinya, diantaranya yang mengarah pada pengembangan aplikasi berbasis WEB, yang lebih dikenal dengan nama WebGIS. Web-GIS merupakan gabungan antara design grafis pemetaan, peta digital dengan analisa geografis, pemrograman komputer, dan sebuah database yang saling terhubung menjadi satu bagian web design dan web pemetaan. Aplikasi web ini telah diterapkan dalam mendokumentasi, merepresentasi data geospasial, potensi dan pendayagunaan sumber daya wilayah kabupaten Grobogan secara komprehensif, sehingga dapat bermanfaat untuk mendistribusi dan mengambil data dan informasi secara online bagi pihak-pihak yang membutuhkan dan berkepentingan dalam pengambilan keputusan. Kebutuhan akan keberadaan serta penyediaan data dan informasi yang lengkap, akurat, cepat dan juga dapat dipertanggungjawabkan dalam upaya pengelolaan dan pengoptimalan potensi dan pendayagunaan sumber 
daya wilayah daerah pada kabupaten Grobogan yang mendukung peluang daerah kabupaten Grobogan bagi pemanfaatan dan pendayagunaan sumber daya wilayah tersebut, terutama bagi mata pencaharian penduduk desa, selain juga mendorong minat para calon investor dalam memilih dan memutuskan pilihan berinvestasi (Dwiati \& Khristianto, 2014)

Penelitian ini bertujuan untuk menganalisis model logit dalam hubungan karakteristik sumber daya manusia seperti pendidikan baik formal maupun informal, usia dan masa kerja terhadap peningkatan kinerja di lingkungan industri informasi geospasial. Penggunaan ketiga variabel tersebut berdasarkan beberapa pertimbangan diantaranya bahwa pendidikan baik formal maupun informal dapat mencerminkan pengetahuan yang dimiliki, masa kerja mempengaruhi kemampuan dalam pelaksanaan teknis pekerjaan sedangkan usia menunjukkan tingkat kedewasaan dan kematangan emosi yang akan mempengaruhi tingkat pelayanan.

Penelitian tentang pengaruh self-esteem, kematangan emosi dan kematangan sosial terhadap kualitas pelayanan pada pasien di Rumah Sakit Ros Tembaga Pura menyimpulkan bahwa baik secara parsial maupun simultan terdapat pengaruh positif dari kematangan diri, kematangan emosi dan kematangan sosial terhadap pelayanan kepada pasien dan kematangan emosi merupakan variabel yang memiliki pengaruh terbesar terhadap kualitas pelayanan kepada pasien (Hadungdungan, 2016).

Faktor-faktor yang berpengaruh terhadap penyesuaian diri adalah kematangan intelektual, moral, emosi dan sosial. Penyesuaian diri adalah interaksi seseorang secara kontinyu dengan dirinya sendiri, orang lain, dan lingkungan disekitarnya. Hasil uji hipotesis menunjukkan adanya hubungan yang signifikan antara kematangan emosi dan keterampilan sosial dengan penyesuaian diri pada santri pondok pesantren Daar Al Furqon Kudus (Ghofiniyah, E., \& Setiowati, 2017)

Sejatinya SDM dengan pendidikan yang memadai, masa kerja tinggi dan telah mengikuti pelatihan terkait informasi geospasial dapat menunjukkan prestasi yang lebih baik. Bukan sebaiknya sebagaimana disampaikan oleh Bardono (2017) bahwa terdapat kesenjangan kompetensi, pada level pendidikan tertentu, tidak ada perbedaan dalam tingkat analisis dengan pegawai pada level operator. Penelitian ini bermaksud untuk membuktikan pernyataan tersebut. Penggunaan model logit untuk melihat keterkaitan karakteristik sumber daya manusia dengan kinerja pegawai di lingkungan industri informasi geospasial belum banyak dilakukan, sehingga penelitian ini diharapkan dapat memberikan kontribusi terkait hal tersebut.

\section{RUANG LINGKUP}

Sumber daya manusia adalah pegawai yang siap, mampu dan siaga dalam mencapai tujuan organisasi. Sumber daya manusia berkualitas tinggi adalah sumber daya manusia yang menciptakan bukan saja nilai komparatif tetapi juga nilai kompetitif generatif-inovatif dengan menggunakan energi tertinggi seperti: intelligence, creativity dan imagination; tidak lagi semata-mata menggunakan energi kasar, seperti bahan mentah, lahan air, tenaga, otot dan sebagainya. Menurut Sugeng (2002) dalam (Kulla, Rumapea, \& Tampongangoy, 2018), bahwa kualitas sumber daya manusia merupakan pengetahuan, keterampilan, dan kemampuan seseorang yang dapat digunakan untuk menghasilkan layanan profesional.

Penelitian tentang pengaruh karakteristik manusia terhadap kinerja secara umum telah cukup banyak dilakukan, tetapi penelitian yang khusus membahas sumber daya manusia yang bekerja pada industri geospasial masih terbatas. Penelitian pendahuluan tentang pengaruh karakteristik manusia terhadap kinerjanya memberikan gambaran bahwa motif, sifat, konsep diri, pengetahuan dan keterampilan secara bersamaan maupun terpisah berpengaruh signifikan terhadap kinerja pegawai, dengan besarnya pengaruh bersamaan adalah $37,9 \%$. Selain itu, sub variabel sifat memiliki pengaruh paling besar terhadap kinerja pegawai, yaitu sebesar 9,18\% (Putri, 2015). Penelitian lainya tentang pengaruh kompetensi sumber daya manusia terhadap kinerja menyimpulkan bahwa kompetensi SDM merupakan faktor yang dapat mempengaruhi kinerja karyawan. Menurut hasil penelitian ini, terdapat lima karakteristik kompetensi yang dapat mempengaruhi kinerja karyawan yaitu, motives, traits, self-concept, knowledge dan skills. Bila karyawan memiliki kompetensi yang tinggi maka kinerja karyawan yang baik dapat terwujud. Penelitian dilakukan menggunakan metode kuantitatif pada 50 orang karyawan PT.Tresnamuda Sejati cabang Surabaya. Berdarakan uji data menggunakan regresi linier berganda dengan bantuan program SPSS dapat membuktikan bahwa kompetensi SDM mempunyai pengaruh secara simultan dan parsial terhadap kinerja karyawan (Callista, 2016).

Penelitian tentang pengaruh pendidikan dan pelatihan terhadap kinerja karyawan melalui variabel mediator kemampuan kerja karyawan pada PT Petrokimia Gresik, dengan populasi berjumlah 3.064 orang dengan sampel berjumlah 97 orang dengan menggunakan teknik proportional random sampling menyimpulkan bahwa pendidikan berpengaruh secara signifikan terhadap kemampuan kerja karyawan (Ratnasari, 2018).

Penelitian yang lebih mendalam tentang karakteristik SDM khususnya pada industri geospasial masih sangat diperlukan untuk mengetahui apakah SDM yang tersedia telah memenuhi harapan memiliki kinerja baik dan dapat diandalkan berdasarkan pada beberapa karakteristik seperti pendidikan, usia dan masa kerja.

Permasalahan utama dari penelitian ini adalah apakah terdapat peluang yang signifikan pada kinerja SDM IG dalam bidang industri geospasial ditinjau dari beberapa karakteristik seperti pendidikan, masa kerja dan usia. Seberapa besar perbedaan peluang kinerja SDM IG 
berdasarkan pada aspek pendidikan, masa kerja dan usia masyarakat. Berdasarkan pada batasan permasalahan tersebut, dapat dirumuskan hipotesis penelitian sebagai berikut :

$\mathrm{Ho}_{1}=$ Tidak terdapat perbedaan peluang yang signifikan pada kinerja SDM IG yang berpendidikan sekolah menengah kejuruan dengan yang berpendidikan sekolah menengah umum / atas yang bekerja pada sektor industri geospasial

$\mathrm{Ha}_{1}=$ Terdapat perbedaan peluang yang signifikan pada kinerja SDM IG yang berpendidikan sekolah menengah kejuruan dengan yang berpendidikan sekolah menengah umum / atas yang bekerja pada sektor industri geospasial

$\mathrm{Ho}_{2}=$ Tidak terdapat perbedaan peluang yang signifikan pada kinerja SDM IG yang pernah mengikuti pelatihan dibidang IG dengan yang belum pernah mengikuti pelatihan / kursus terkait industri geospasial.

$\mathrm{Ha}_{2}=$ Terdapat perbedaan peluang yang signifikan pada kinerja SDM IG yang pernah mengikuti pelatihan dibidang IG dengan yang belum pernah mengikuti pelatihan / kursus terkait industri geospasial.

$\mathrm{Ho}_{3}=$ Tidak terdapat perbedaan peluang yang signifikan pada kinerja SDM IG yang memiliki masa kerja < dari 5 tahun dengan yang memiliki masa kerja > 10 tahun pada industri geospasial

$\mathrm{Ha}_{3}=$ Terdapat perbedaan peluang yang signifikan pada kinerja SDM IG yang memiliki masa kerja < dari 5 tahun dengan yang memiliki masa kerja >10 tahun pada industri geospasial

$\mathrm{Ho}_{4}=$ Tidak terdapat perbedaan peluang yang signifikan pada kinerja SDM IG yang memiliki masa kerja antara 5 s.d. 10 tahun dengan yang memiliki masa kerja > 10 tahun pada industri geospasial

$. \mathrm{Ha}_{4}=$ Terdapat perbedaan peluang yang signifikan pada kinerja SDM IG yang memiliki masa kerja antara 5 s.d. 10 tahun dengan yang memiliki masa kerja > 10 tahun pada industri geospasial

$\mathrm{Ho}_{5}=$ Tidak terdapat perbedaan peluang yang signifikan pada masyarakat kota Bogor yang berusia $<35$ tahun dengan yang berusia $>50$ tahun dalam bekerja pada industri geospasial

$\mathrm{Ha}_{5}=$ Terdapat perbedaan peluang yang signifikan pada masyarakat kota Bogor yang berusia < 35 tahun dengan yang berusia $>50$ tahun dalam bekerja pada industri geospasial

$\mathrm{Ho}_{6}=$ Tidak terdapat perbedaan peluang yang signifikan pada masyarakat kota Bogor yang berusia 35 s.d 50 tahun dengan yang berusia > 50 tahun dalam bekerja pada industri geospasial
$\mathrm{Ha}_{6}=$ Terdapat perbedaan peluang yang signifikan pada masyarakat kota Bogor yang berusia antara 35 s.d. 50 tahun dengan yang berusia > 50 tahun dalam bekerja pada industri geospasial

Untuk membuktikan hipotesis 1 sampai 6, digunakan pendekatan regresi linier binary logistik. Penggunaan model logit ini disebabkan karena data yang digunakan baik untuk variabel $\mathrm{X}$ maupun variabel $\mathrm{Y}$ merupakan data kualitatif dengan dummy. Model logit adalah model non-linier baik dalam parameter maupun dalam variabel, oleh karena itu metode OLS tidak dapat digunakan untuk mengestimasi model logit. Model logit banyak digunakan dalam menganalisis masalah ketenagakerjaan. Misalnya apabila ingin diketahui bahwa terdapat pengaruh pendidikan, usia dan masa kerja seseorang terhadap kinerjanya, maka hipotesis yang dibangun adalah karakteristik individu terhadap kinerja. Berdasarkan beberapa penelitian terdahulu sebagaimana telah dijelaskan sebelumnya, terdapat beberapa variabel yang diduga berpengaruh terhadap kinerja pegawai, diantaranya adalah tingkat pendidikan, usia dan masa kerja. Ketiga variabel tersebut akan menentukan apakah seseorang memiliki kinerja baik atau sebaliknya. Tingkat pendidikan, usia dan masa kerja memiliki hubungan positif dan berbanding lurus dengan kinerja. Sejatinya semakin tinggi pendidikan, semakin lama masa kerja dan semakin tinggi usia seseorang, akan semakin baik juga kinerjanya. Berdasarkan pada kerangka berfikir tersebut, kinerja individu khususnya sumber daya manusia industri geospasial (SDM IG) yang dipengaruhi oleh karakteristiknya ditunjukkan pada gambar 1 .

\section{Gambar 1. Rerangka Konseptual}

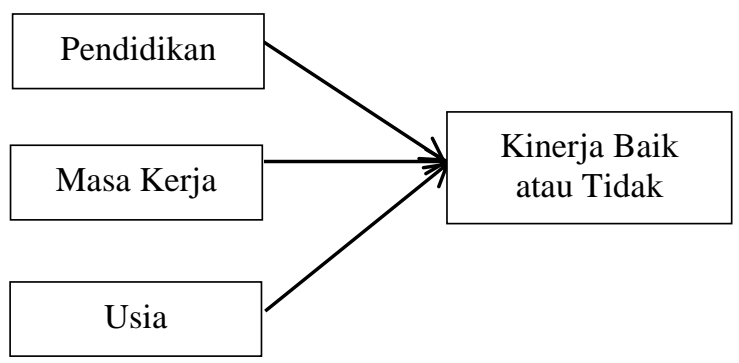

\section{BAHAN DAN METODE}

Pengembangan sumber daya manusia yang profesional atau continuing professional development (CPD) adalah cara yang profesional untuk mempertahankan pengetahuan dan keterampilan yang diperlukan dalam pekerjaan. Pengembangan SDM diperlukan untuk pelaksanaan tugas profesional dan teknis sepanjang karir. CPD didefinisikan sebagai sebuah strategi belajar yang sistematis dan berkelanjutan untuk menuju kepada pertumbuhan dan perkembangan kecakapan profesional 
yang memadai sehingga memungkinkan seorang profesional berperan secara maksimal dan berhasil dalam lingkungan yang senantiasa berubah yang bertujuan untuk menjembatani kesenjangan pengetahuan dan kecakapan (knowledge gap) yang telah didapat melalui pendidikan formal dengan dunia nyata di lapangan.

Tujuan pengembangan SDM IG yang professional diantaranya adalah untuk meningkatkan kompetensi professional, mematuhi peraturan yang berlaku di bidang profesi, memperoleh pengetahuan dan keterampilan yang dibutuhkan, serta kemajuan teknologi. Beberapa hal yang dapat dilakukan adalah melalui peningkatan pendidikan akademik dan profesi, memelihara kompetensi melalui sertifikasi, mengikuti diklat atau pelatihan profesi, memelihara keahlian dan kode etik. Konsep pengembangan SDM IG sebagaimana terdapat dalam gambar 2.

\section{Konsep Pengembangan SDM Informasi Geospasial}

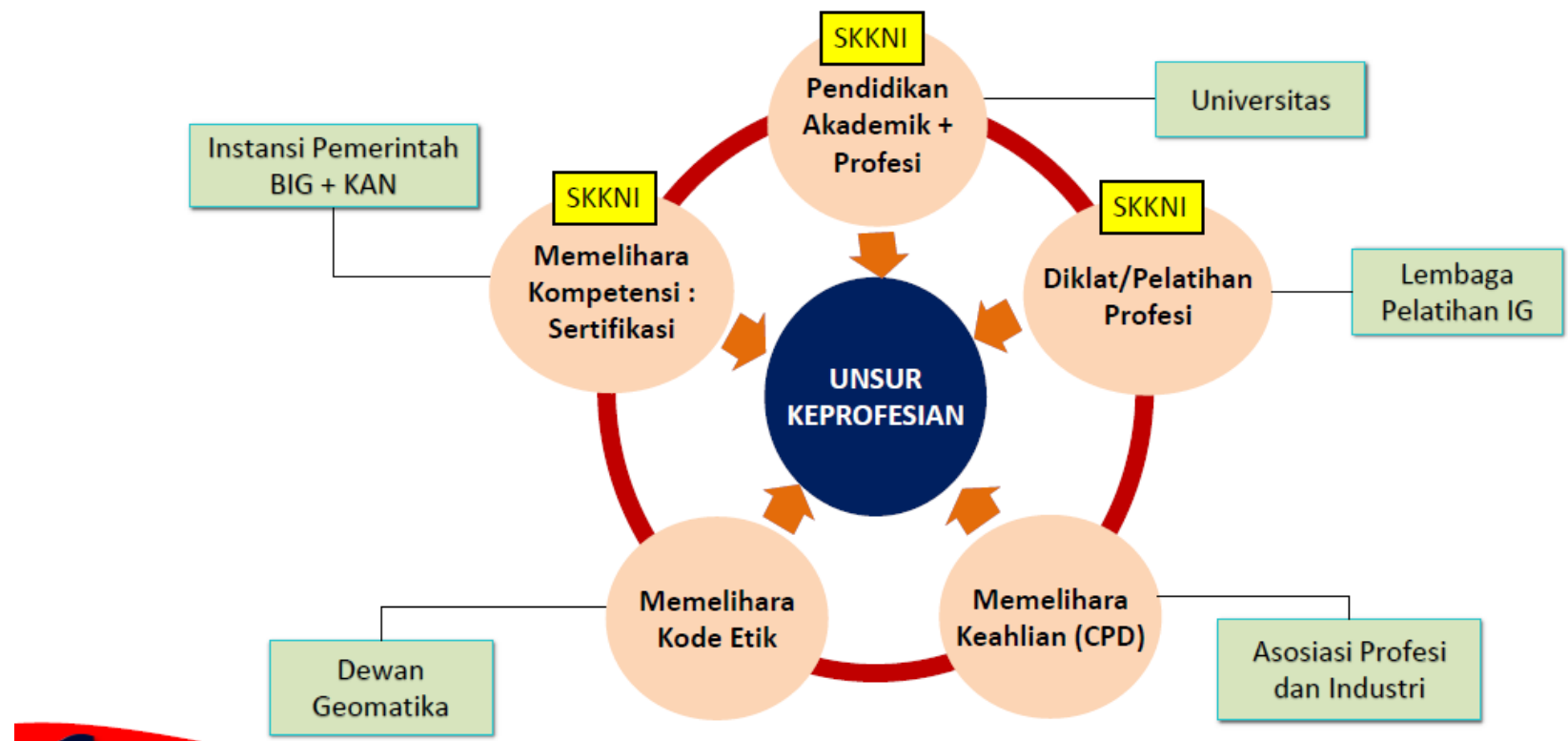

Secara etimologi profesi dari kata profession yang berarti pekerjaan. Professional artinya orang yang ahli atau tenaga ahli. Profesi adalah suatu bentuk pekerjaan yang mengharuskan pelakunya memiliki pengetahuan tertentu yang di peroleh melalui pendidikan formal dan keterampilan tertentu yang di dapat melalui pengalaman kerja pada orang yang terlebih dahulu menguasai keterampilan tersebut, dan terus memeprbaharui keterampilannya sesuai dengan perkembangan teknologi.

Seorang yang professional adalah seseorang yang menjalankan profesinya secara benar dan melakukannya menurut etika dan garis-garis profesionalisme yang berlaku pada profesinya tersebut. Untuk menjadi seorang yang professional, seseorang yang melakukan pekerjaan di tuntut untuk memiliki komitmen yang kuat pada pekerjaan yang sedang di lakukan, tanggung jawab penuh terhadap pekerjaan yang di lakukannya sendiri, berpikir sistematis tentang apa yang di lakukannya dan belajar dari pengalamannya, penguasaan materi pekerjaan secara mendalam, menjadi bagian masyarakat dalam lingkungan profesinya.

Profesionalisme dalam bidang kedokteran menjadi kompetensi utama yang wajib dikuasai oleh seorang dokter. Kajian untuk mendapatkan pemahaman tentang profesionalisme dan metode pembelajaran yang dapat diaplikasikan pada institusi kedokteran telah menyimpulkan bahwa profesionalisme kedokteran adalah integrasi kemampuan dan penguasaan dalam keilmuan, keterampilan serta sikap. Sikap menjadi dasar terbentuknya perilaku profesional. Profesionalisme dapat dipelajari dan diajarkan melalui metode yang bersifat implisit, eksplisit dan pembelajaran berkelanjutan. Pembelajaran profesionalisme kedokteran dapat dikolaborasikan dalam beberapa metode pembelajaran. Role model dinyatakan sebagai metode pembelajaran yang efektif dalam usaha pembelajaran profesionalisme kedokteran dan penguasaan perilaku profesionalnya (Cicih Bhakti Purnamasari, Mora Claramita, \& Prabandari, 2017) 


\subsection{Sumber dan Bentuk Data}

Untuk mengetahui apakah SDM IG yang bekerja di lingkungan industri geospasial (IG) telah memiliki kinerja baik atau tidak, telah dilakukan penyebaran kuesioner pada beberapa perusahaan IG yang berlokasi di beberapa wilayah di Indonesia. Jumlah responden yang berpartisipasi dalam penelitian ini sebanyak 46 responden yang bekerja pada perusahaan IG. Dari jumlah tersebut sebanyak $28(61 \%)$ responden berusia < 35 tahun, $15(33 \%)$ responden berusia antara 35 s.d 50 tahun dan hanya $3(6 \%)$ responden berusia $>50$ tahun. Usia dan pengalaman hidup seseorang merupakan faktor penting yang dapat mempengaruhi persepsi. Berdasarkan pada kategori pendidikan baik formal maupun informal, dari 46 responden, SDM IG yang berijazah SMU/SMA berjumlah 36 (78\%), SMK berjumlah 10 (22\%). Yang memiliki sertifikat pelatihan / kursus di bidang IG berjumlah 26 (56\%) sedangkan yang tidak memiliki kursus atau pelatihan pada bidang tersebut sebanyak 20 (44\%) responden. Berdasarkan lamanya bekerja, diperoleh data bahwa responden yang memiliki masa kerja $<5$ tahun sebanyak 14 (30\%), memiliki masa kerja antara 5 s.d. 10 tahun sebanyak 15 (33\%) dan yang memiliki masa kerja > 50 tahun sebanyak 17 (37\%) responden.

Data yang telah terkumpul selanjutnya akan diolah menggunakan PASW Statistics SPSS 18 dengan model regresi linier binary logistic atau model logit. Penggunaan model ini dengan pertimbangan baik variabel dependent maupun independent merupakan data kualitatif dengan dummy variabel. Variabel dependent atau variabel terikat berkaitan dengan apakah SDM IG memiliki kinerja baik atau tidak dengan $\mathrm{p}=0$; memiliki kinerja tidak baik, dan $\mathrm{p}=1$; memiliki kinerja baik. Variabel independent atau variabel bebas juga merupakan data kualitatif yang akan dirubah menjadi data kategorik dengan satu kategorik pembandingnya (reference). Variabel bebas ini terdiri dari beberapa faktor yaitu pendidikan, masa kerja, usia. Pendidikan akan dibagi atas pendidikan formal yang terdiri dari SMU dan SMK, dan pendidikan informal yaitu pelatihan atau kursus terkait bidang IG dengan SMU dan pelatihan/kursus pada bidang non IG, sebagai variabel pembanding (reference). Variabel kategorik pembanding bernilai 2, pendidikan SMK dan Kursus IG bernilai 1. Lamanya bekerja terbagi atas masa kerja $<5$ tahun dan masa kerja antara 5 s.d. 10 tahun, masa kerja $>10$ tahun sebagai pembanding (reference). Variabel kategorik pembanding bernilai 3 , masa kerja $<5$ tahun dan masa kerja antara 5 s.d. 10 tahun, bernilai 1 dan 2. Sedang usiaakan dibagi atas umur dibawah 35 tahun, antara 35 sampai 50 tahun dan umur diatas 50 tahun dengan umur diatas 50 tahun sebagai reference atau pembanding. Variabel kategorik pembanding bernilai 3, umur antara 35 - 50 tahun bernilai 2 dan umur kurang dari 35 tahun bernilai 1. Categorical variabel codings dapat dilihat pada tabel 1 .
Tabel 1. Categorical Variables Codings

\begin{tabular}{|l|c|c|c|}
\hline Parameter & Freq & \multicolumn{2}{|c|}{ Parameter Coding } \\
\hline & & $(1)$ & $(2)$ \\
\hline Usia 1 & 28 & 1,000 & 0.000 \\
\hline Usia 2 & 15 & 0.000 & 1.000 \\
\hline Usia 3 & 3 & 0.000 & 0,000 \\
\hline Pend. Formal 1 & 10 & 1,000 & 0.000 \\
\hline Pend. Formal 2 & 36 & 0.000 & 0.000 \\
\hline Pend. Informal 1 & 26 & 1,000 & 0.000 \\
\hline Pend. Informal 2 & 20 & 0.000 & 0.000 \\
\hline Masa Kerja 1 & 14 & 1,000 & 0.000 \\
\hline Masa Kerja 2 & 15 & 0.000 & 1,000 \\
\hline Masa Kerja 3 & 17 & 0.000 & 0.000 \\
\hline
\end{tabular}

Setelah data siap olah, langkah selanjutnya adalah membuat model logistik. Model yang akan dihasilkan pada regresi linier binary logistic adalah sebagai berikut : (Nachrowi \& Usman, 2006)

$\operatorname{Ln}\left(\frac{\mathrm{p}}{1-\mathrm{p}}\right)=\alpha+\beta_{1}$ usia $1+\beta_{2}$ usia $2+\gamma_{1}$ pend $1+$

$\gamma_{2}$ pend $2+\delta_{1}$ mskrja $1+\delta_{2}$ mskerja

Pembahasan dua model alternatif untuk data biner yaitu model Regressi Logit dan Probit. Regressi Logit digunakan untuk menggambarkan hubungan variabel dependen (variabel respon) dengan variabel independen (variabel prediktor) yang bersifat kategori, kontinu atau kombinasi keduanya. Sedangkan regresi Probit adalah suatu analisis regresi yang digunakan untuk menggambarkan hubungan antara variabel dependen dan variabel independen. Variabel dependen (variabel respon) biasa disimbolkan $\mathrm{Y}$ dengan skala pengukuran dikotomus (biner), dan variabel independen (variable prediktor) biasa disimbolkan $\mathrm{X}$ yang skala pengukuran bersifat dikotomus, polikotomus atau kontinu. Untuk pendugaan parameter pada model regresi dan regresi Logit digunakan Metode Maksimum Likelihood (Tinungki, 2010).

Model logit dapat diterapkan pada pengujian hubungan Indeks Prestasi Kumulatif (IPK) sebagai indikator keberhasilan mahasiswa program studi Matematika dan Kimia FMIPA Universitas Samratulangi (Unsrat) Manado serta mengetahui faktorfaktor yang mempengaruhi IPK tersebut dengan populasi berjumlah responden sebanyak 86 mahasiswa. Hasil penelitian menunjukkan bahwa program studi dan tempat tinggal berpeluang memiliki pengaruh terhadap Indeks Prestasi Kumulatif (IPK) mahasiswa di FMIPA Unsrat Manado (Tampil, Komaliq, \& Langi, 2017).

Untuk memudahkan dalam pembahasan penelitian ini, analisis akan dilakukan dalam beberapa bagian yaitu ; Pertama, analisis terhadap uji wald untuk parameter regresi (uji t pada regresi). Uji wald bertujuan untuk 
menguji hipotesis sehingga dapat diketahui apakah hipotesis nol signifikan atau tidak pada alfa 5\%. Kedua ; interpretasi berdasarkan pada odd ratio. Interpretasi pada odd ratio ini bertujuan untuk mengetahui seberapa besar kecenderungan setiap kategorik dibandingkan dengan kategorik pembandingnya.

\subsection{Hasil Pengolahan Data}

Berdasarkan data yang terdapat pada tabel 2, persamaan model logit dapat diformulasikan sebnagai nerikut : (Nachrowi \& Usman, 2006)

$$
\begin{aligned}
& \operatorname{Ln}\left(\frac{p}{1-p}\right)=-21,996+20,76 \text { usia } 1+20,613 \text { usia } 2+ \\
& 1,077 \text { pend } 1+0,307 \text { pend } 2+0,433 \text { mskrja } 1+ \\
& 0,569 \text { mskerja }
\end{aligned}
$$

\section{Table 2. Variabel in Equation}

\begin{tabular}{|l|l|c|l|c|l|}
\hline Uraian & B & Wald & df & Sig. & Exp(B) \\
\hline Usia1 & 20,763 & 0,000 & 1 & 0,999 & $1,041 \mathrm{E} 9$ \\
\hline Usia2 & 20,613 & 0,000 & 1 & 0,999 & $8,955 \mathrm{E} 8$ \\
\hline Pend.1 & 1,077 & 1,344 & 1 & 0,246 & 2,937 \\
\hline Pend.2 & 0,307 & 0,191 & 1 & 0,662 & 1,359 \\
\hline Mskrj1 & 0,433 & 0,276 & 1 & 0,599 & 1,542 \\
\hline Mskrj2 & 0,569 & 0,487 & 1 & 0,485 & 1,766 \\
\hline Constant & $-21,966$ & 0,000 & 1 & 0,999 & 0,000 \\
\hline
\end{tabular}

Dengan nilai intercept sebesar -21,996, berarti pada saat dimasukkan nilai 0, yang berarti bahwa masyarakat berpendidikan SMU, belum atau tidak mengikuti pelatihan di bidang geospasial dengan masa kerja lebih dari 10 tahun dan berusia lebih dari 50 tahun berpeluang memiliki kinerja yang baik sangat tidak signifikan yaitu sebesar $3 \times 10^{-9}$ sebesar $3 \times 10^{-7} \%$.

$$
\begin{aligned}
& \text { Ln }(\mathrm{P} / 1-\mathrm{P})=\text { intercept }(\text { Nachrowi \& Usman, 2006) } \\
& \operatorname{Ln}(\mathrm{P} / 1-\mathrm{P})=-21,996 \\
& (\mathrm{P} / 1-\mathrm{P})=\operatorname{Exp}(-21,996) \\
& (\mathrm{P} / 1-\mathrm{P})=0,0000000003 \\
& P=\frac{0,0000000003}{1+0,000000003} P=\frac{0,0000000003}{1,0000000003} \\
& P=\frac{0,0000000003}{1,0000000003} \mathrm{P}=0,0000000003=3 \times 10^{-9}
\end{aligned}
$$

Berdasarkan uji $\mathrm{G}$ didapat nilai -2 log likelihood sebesar 58,096 menunjukkan semua variabel dapat dimasukkan dalam moidel. Uji koefisien secara individu yang dilakukan dengan uji wald menunjukkan variabel pendidikan 1 tidak signifikan pada alfa 5\% artinya tidak ada perbedaan peluang yang signifikan antara kinerja SDM yang berpendidikan SMU dengan kinerja pegawai yang berpendidikan SMK dalam memiliki kinerja yang baik di bidang industri geospasial. Begitu pula halnya dengan pendidkn2, dengan signifikansi lebih besar dari $5 \%$, artinya tidak ada perbedaan peluang yang signifikan antara SDM yang pernah mengikuti pelatihan di bidang geospasial dengan yang tidak mengikuti pelatihan di bidang yang sama. Begitu pula dengan variable usia1, menunjukkan tidak signifikan pada alfa 5\% artinya tidak ada perbedaan peluang yang signifikan antara SDM yang berusia < 35 tahun dengan yang berusia > 50 tahun dalam memiliki kinerja yang baik di bidang industri geospasial. Begitu pula dengan variable usia2, menunjukkan tidak signifikan pada alfa 5\% artinya tidak ada perbedaan peluang yang signifikan antara SDM yang berusia $35-50$ tahun dengan yang berusia $>50$ tahun dalam memiliki kinerja yang baik di bidang industri geospasial.

Variable masakerja1, menunjukkan tidak signifikan pada alfa $5 \%$ artinya tidak ada perbedaan peluang yang signifikan antara SDM yang memiliki masa kerja $<5$ tahun dengan yang memiliki masa kerja > 10 tahun dalam memiliki kinerja yang baik di bidang industri geospasial. Begitu pula dengan variable usia2, menunjukkan tidak signifikan pada alfa 5\% artinya tidak ada perbedaan peluang yang signifikan antara SDM yang berusia $5-10$ tahun dengan yang memiliki masa kerja > 10 tahun dalam memiliki kinerja yang baik di bidang industri geospasial.

Interpretasi berdasarkan odd ratio dan exp (B) pada usia1 bernilai 1,041E9 menunjukkan adanya peluang/kecenderungan SDM yang berusia < 35 tahun memiliki kinerja baik 1,041E9 kali daripada mereka yang berusia > 50 tahun, sedangkan SDM yang berusia antara 35 - 50 tahun memiliki kinerja baik 8,955E8 kali daripada mereka yang berusia $>50$ tahun.

Interpretasi berdasarkan exp (B) pada SDM yang berpendidikan SMK bernilai 2,937 artinya peluang/kecenderungan SDM yang berpendidikan SMK 2,937 kali SDM yang memiliki pendidikan SMU. sedangkan SDM yang pernah mengikuti pelatihan dalam bidang geospasial memiliki peluang berkinerja baik 1,359 kali SDM yang tidak mengikuti pelatihan di bidang geospasial

Interpretasi berdasarkan exp (B) pada SDM yang memiliki masa kerja < 5 tahun bernilai 1,542 artinya peluang/kecenderungan SDM yang memiliki masa kerja $<5$ tahun 1,542 kali SDM yang memiliki masa kerja > 10 tahun. sedangkan SDM yang memiliki masa kerja antara $5-10$ tahun memiliki peluang berkinerja baik 1,766 kali SDM yang memiliki masa kerja > 10 tahun.

\section{KESIMPULAN}

Berdasarkan pada uji koefisien secara individu yang dilakukan dengan uji wald menunjukkan SDM IG dengan karakteristik yang usia > $>$ tahun, berpendidikan SMU dengan masa kerja $>10$ tahun tidak memiliki peluang yang signifikan untuk berkinerja baik. Kecenderungan ini menunjukkan pendidikan SMK/SMU/SMA belum mampu memberikan keahlian 
sebagaimana yang diharapkan, demikian pula dengan faktor usia dan masa kerja. Meskipun telah memiliki masa kerja dan usia yang lebih lama, tidak memberikan peluang memiliki kinerja lebih baik. Interpretasi berdasarkan odd ratio dan $\exp (B)$ pada seluruh variabel bebas menunjukkan SDM yang berusia $<35$ tahun dan SDM antara 35 - 50 tahun tidak signifikan memiliki kinerja lebih baik daripada mereka yang berusia $>50$ tahun, begitupula SDM yang berpendidikan SMK, pernah mengikuti pelatihan dalam bidang IG, memiliki masa kerja $<5$ tahun dan $5-10$ tahun tidak signifikan memiliki peluang berkinerja lebih baik daripada SDM yang memiliki masa kerja > 10 tahun.

Hasil penelitian ini konsisten dengan apa disampaikan oleh Bardono (2017) bahwa terdapat kesenjangan kompetensi, dimana pada level pendidikan tertentu tidak ada perbedaan dalam tingkat analisis dengan pegawai pada level operator. Bahkan masa kerja maupun usia yang lebih tinggipun tidak signifikan memberikan perbedaan dalam kinerja pegawai di lingkungan industri informasi geospasial.

\section{SARAN}

Berdasarkan pada kesimpulan, sebagaimana hasil penelitian-penelitian terdahulu, bahwa kendala yang dihadapi dalam mengembangkan industri geospasial adalah pada faktor sumber daya manusia yang belum sesuai harapan. Peningkatan kompetensi dan professionalisme merupakan tantang berat yang harus dihadapi. Saran untuk penelitian selanjutnya adalah dengan menambah jumlah responden serta merubah kategori pembanding (reference).

\section{DAFTAR PUSTAKA}

Abidin, H. Z. (2017). Pengembangan SDM Informasi Geospasial Untuk Kebutuhan Pembangunan Nasional dan Menghadapi Tantangan Globalisasi. (November). https://doi.org/10.13140/RG.2.2.34250.47047

Bardono, S. (2017). One Certificate Policy Tingkatkan Kualitas Kompetensi SDM IG. Retrieved from https://technology-indonesia.com/lain-lain/umumlain-lain/one-certificate-policy-tingkatkan-kualitaskompetensi-sdm-ig/

Cahaya, S. (2018). Sistem Informasi Geografis Data Base Rumah Sakit dan Pusat Kesehatan Masyarakat di Kabupaten Lampung Timut. Высшей Нервной Деятельности, 2, 227-249. Retrieved

from http://digilib.unila.ac.id/55321/3/SKRIPSI TANPA BAB PEMBAHASAN.pdf

Callista, N. (2016). Pengaruh Kompetensi SDM Terhadap Kinerja Karyawan Pada Pt.tresnamuda Sejati Cabang Surabaya. Agora, 4(2), 45-50. Retrieved from https://media.neliti.com/media/publications/57287ID-pengaruh-kompetensi-sdm-terhadap-kinerja.pdf
Cicih Bhakti Purnamasari, Mora Claramita, \& Prabandari, yayi suryo. (2017). Pembelajaran Profesionalisme Kedokteran dalam Persepsi Instruktur dan Mahasiswa. Jurnal Pendidikan Kedokteran Indonesia; The Indonesian Journal of Medical Education, 4(1), 21-27.

Dwiati, T., \& Khristianto, T. (2014). Pemodelan Aplikasi Informasi Geospasial Potensi dan Pendayagunaan Sumber Daya Wilayah serta Matapencaharian Penduduk Desa Kabupaten Grobogan berbasis WebGIS. 19(1), 86-94. Retrieved from https://www.google.com/search?q=aplikasi+data+b ase+geospasioal+dalam+kehidupan \&rlz=1C1RUC Y_idID863ID863\&oq=aplikasi+data+base+geospa sioal+dalam+kehidupan $\&$ aqs $=$ chrome. $.69 i 57 j 33.90$ $16 j 0 \mathrm{j} 8 \&$ sourceid $=$ chrome $\& \mathrm{ie}=\mathrm{UTF}-8$

Ghofiniyah, E., \& Setiowati, E. A. (2017). Penyesuaian Diri Pada Santri Pondok Pesantren Daar Al Furqon Kudus. Jurnal Psikologi, 12(1), 1-16. Retrieved from file:///C:/Users/user/Downloads/2844-64581-SM (2).pdf

Hadungdungan, S. (2016). Pengaruh Self-Esteem , Kematangan Emosi Dan Kematangan Sosial Terhadap Kualitas Pelayanan pada Pasien di Rumah Sakit Ros Tembaga Pura. 79. Retrieved from epository.ut.ac.id/7239/1/42740.pdf

Hamidi, H. (2012). Aplikasi Sistem Informasi Geografis Berbasis Web Penyebaran Dana Bantuan Oerasional Sekolah. Jurnal Masyarakat Informatika, V, 2(3), 1-14. Retrieved from ttps://media.neliti.com/media/publications/113546ID-aplikasi-sistem-informasi-geografis-berb.pdf

Kulla, T., Rumapea, P., \& Tampongangoy, D. L. (2018). Kualitas Sumber Daya Manusia dalam Meningkatkan Pembangunan Desa Tinggilbet Distrilk Beoga Kabupaten Puncak Provinsi Papua. Retrieved from file://C:/Users/user/Downloads/19785-40103-1SM (1).pdf

LAPAN. (2014). Pengembangan infrastruktur informasi geospasial pemanfaatan penginderaan jauh. Retrieved from usfatja.lapan.go.id/files_uploads_ebook/publikasi/ Buku Laporan 2014 Final/000_SPBN_final.pdf

Nachrowi, N. D., \& Usman, H. (2006). Pendekatan Populer dan Praktis Ekonometrika Untuk Analisis Ekonomi dan Keuangan (1st ed.). Jakarta: Lembaga Penerbit Fakultas Ekonomi.

Nurhayati, I., Susetyo, B., Eosina, P., \& Purnahayu, I. (2017). Analisis Daya Saing Industri Informasi Geospasial di Indonesia. Prosiding Seminar Nasional XII "Rekayasa Teknologi Industri Dan Informasi 2017 Sekolah Tinggi Teknologi Nasional Yogyakarta, 16. Retrieved from file://C:/Users/user/Downloads/607-Article Text2190-1-10-20180312 (1).pdf

Putri, E. M. (2015). Pengaruh Faktor-Faktor Kompetensi Sumber Daya Manusia terhadap Kinerja Pegawai 
dalam Implementasi Sistem e-Procurement (Studi Kasus pada Kementerian Pekerjaan Umum). Retrieved from http://repository.its.ac.id/1112/1/9112202814Master-Theses.pdf

Ramlan, F. M., Purwanto, E. H., Eosina, P., \& Susetyo, B. (2019). Sistem Informasi Pemasaran Rumah Berbasis Web GIS (Studi Kasus: Perumahan Bukit Sakinah). Seminar Nasional Geomatika, 3, 433. https://doi.org/10.24895/sng.2018.3-0.983

Ratnasari, M. D. (2018). Pengaruh pendidikan dan pelatihan terhadap Kinerja Karyawan melalui variabel mediator kemampuan kerja karyawan (Studi Pada Karyawan PT Petrokimia Gresik ). Jurnal Administrasi Bisnis (JAB)|, 58(1), 210-218. Retrieved
file:///C:/Users/user/Downloads/2423-9656-1PB.pdf

Tampil, Y., Komaliq, H., \& Langi, Y. (2017). Analisis Regresi Logistik Untuk Menentukan Faktor-Faktor Yang Mempengaruhi Indeks Prestasi Kumulatif (IPK) Mahasiswa FMIPA Universitas Sam Ratulangi Manado. d'CARTESIAN, 6(2), 56. https://doi.org/10.35799/dc.6.2.2017.17023

Tinungki, G. M. (2010). Aplikasi Model Regresi Logit dan Probit pada Data Kategorik. Jurnal Matematika, Statistika \& Komputasi, 6(2), 107$114 . \quad$ Retrieved from file://C:/Users/user/Downloads/3359-6683-1-SM (1).pdf 